\title{
PENINGKATAN MOTIVASI BELAJAR BIOLOGI SISWA KELAS X.3 MELALUI MODEL GROUP INVESTIGATION (GI) PADA MATERI AVERTEBRATA DI SMA NEGERI I PAJANGAN TAHUN AJARAN 2011/2012
}

\author{
Efi Solina Fitri, Muhammad Joko Susilo
}

\begin{abstract}
ABSTRAK
$\mathrm{P}$ embelajaran yang didominasi guru dengan menggunakan media yang konvensional dapat berpengaruh dalam proses pembelajaran dikelas, begitupula yang terjadi dalam proses pembelajaran di kelas X.3 SMA Negeri I Pajangan bahwa motivasi belajar siswa masih rendah, sehingga masih nampak pembelajaran yang kurang efektif dan belum sepenuhnya melibatkan siswa. oleh karena itu, solusi alternatif yang dapat digunakan sebagai solusi adalah menerapkan pembelajaran tersebut dengan model Group Investigation (GI) dengan tujuan untuk melihat kesesuaian model pembelajaran Group Investigation (GI) dapat diterapkan sesuai dengan langkah-langkah pembelajaran, melihat ketercapaian banyaknya siklus dalam proses ketecapaian pembelajaran dan melihat besarnya peningkatan motivasi belajar biologi siswa kelas X.3 melalui penerapan model pembelajaran Group Investigation (GI) pada materi pembelajaran avertebrata di SMA N I Pajangan tahun ajaran 2011/2012.

Penelitian ini merupakan penelitian tindakan Kelas yang dilakukan di SMA Negeri I Pajangan sebanyak 2 siklus dengan subyek penelitian adalah siswa kelas X.3 sebanyak 32 siswa. Instrumen yang digunakan adalah lembar observasi dan tes obyektif. dengan perolehan data melalui observasi motivasi belajar siswa dan post test sebagai bentuk prestasi dari pengaruh motivasi belajar yang kemudian data dianalisis secara deskriptif.

Penerapan model pembelajaran Group Investigation (GI) dapat diterapkan sesuai dengan sintaks - sintaks pembelajaran, dan motivasi belajar siswa mengalami peningkatan dengan perbaikan pembelajaran di siklus II dengan cara guru lebih mendekatkan dengan siswa dan memonitoring dengan baik. Dapat dilihat dari hasil peningkatan motivasi belajar siswa ialah motivasi belajar siswa dalam mengikuti kegiatan pembelajaran meningkat pada siklus I 60,15\% siswa aktif dan 77,82\% pada siklus II. Berdasarkan peningkatan motivasi belajar siswa maka hasil dari belajar atau prestasi siswa juga mengalami peningkatan, yakni ditunjukkan dengan


nilai rata-rata kelas post tes siswa pada siklus I sebesar 65,34 dan 81,45 pada siklus II, sehingga pembelajaran diberhentikan pada siklus II.

Berdasarkan hasil tersebut maka dapat disimpulkan bahwa model pembelajaran Group Investigation (GI) dapat terlaksana sesuai dengan sintaks - sintaks pembelajaran, proses pembelajaran tercapai pada sebanyak 2 siklus, dan motivasi belajar siswa mengalami peningkatan terutama siswa kelas X.3.

Kata kunci: Motivasi belajar, Group Investigation (GI), Avertebrata 


\section{PENDAHULUAN}

Berdasarkan pengalaman dan refleksi yang dilakukan bersamaan dengan guru biologi pada pelaksanaan PPL II pada bulan Juli sampai September 2011 di SMA N 1 Pajangan bahwa pembelajaran masih teacher center, bahkan ada beberapa siswa yang suka berbicara sendiri, kurang memperhatikan guru mengajar dan siswa kurang memanfaatkan kesempatan yang diberikan guru untuk bertanya dan semangat kurang antusiasnya siswa serta hasil ulangan harian yang belum mencapai KKM 100\%. Siswa yang mengalami ketuntasan belajar baru mencapai 45\% dari 32 siswa di kelas X.3.

Permasalahan pembelajaran tersebut muncul karena rendahnya motivasi belajar siswa yang disebabkan siswa belum memahami materi yang disampaikan guru dan mereka tidak memiliki keberanian untuk bertanya maupun menyampaikan ide terkait materi pembelajaran terutama materi avertebrata, karena menggangap materi ini merupakan materi yang dianggap sulit dengan banyaknya pengkelompokan klasifikasi avertebrata dan siswa kurang bersemangat dalam proses pembelajaran. Hal ini masih dijumpai ketika observasi ulang di sekolah pada tanggal 19 Maret 2012 dan berdiskusi dengan $\mathrm{Bu}$ Ratih selaku pengampu guru biologi kelas X denngan harapan ditemukan suatu solusi untuk meningkatakn proses pembelajaran di kelas.

Penggunaan salah satu model pembelajaran diharap dapat meningkatkan keaktifan siswa yang heterogen dalam proses pembelajaran. yang mana siswa kurang berinteraksi secara maksimal dalam pembelajaran di kelas. Oleh karena itu, perlu adanya implementasi model pembelajaran yang mampu meningkatan keaktifan dan peran serta siswa dalam proses kegiatan belajar mengajar. alternatif solusi yang dapat dilakukan guru sebagai bentuk inovasi pembelajaran adalah dengan menerapkan model Group Investigation (GI).

Model Group Investigation (GI) dapat dipandang sebagai suatu pendekatan dalam pembelajaran yang menekankan agar siswa mampu berpikir kreatif dan lebih aktif dalam belajar dan termotivasi. Motivasi merupakan stimulasi atau semangat akibat rangsangan atau kegairahan terhadap sesuatu yang benar-benar diinginkan yaitu motivasi siswa dalam belajar.

Belajar adalah suatu proses untuk mendapatkan perubahan tingkah laku seseorang melalui interaksi dengan lingkungannya. Berbagai kelebihan yang ditawarkan dari Group Investigation (GI) diharapkan dapat meningkatkan motivasi dan hasil belajar biologi siswa kelas X.3 melalui model Group Investigation (GI) pada materi avertebrata di SMAN 1 Pajangan tahun ajaran $2011 / 2012$. 
Penelitian ini bertujuan untuk Melihat kesesuaian langkah - langkah model pembelajaran Group Investigation (GI), melihat ketercapaian banyaknya siklus dalam meningkatkan motivasi belajar biologi siswa kelas X.3 dan untuk melihat besarnya peningkatan motivasi belajar biologi siswa kelas X.3 melalui penerapan model pembelajaran Group Investigation (GI) pada materi avertebrata di SMA Negeri I Pajangan tahun ajaran 2011/2012.

\section{METODE PENELITIAN}

Penelitian ini merupakan penelitian tindakan Kelas kelas atau yang sering disebut dengan Clasroom Action Research, yang dilakukan di SMA Negeri I Pajangan sebanyak 2 siklus dengan subyek penelitian adalah siswa kelas X.3 sebanyak 32 siswa pada bulan mei sampai dengan juli 2012 .

Dengan tiap siklusnya terdiri dari perencanaan, tidakan, observasi, dan refleksi. Instrumen yang digunakan adalah lembar observasi dan tes obyektif. dengan perolehan data melalui observasi motivasi belajar siswa dan post test sebagai bentuk prestasi dari pengaruh motivasi belajar yang kemudian data dianalisis secara deskriptif.

\section{HASIL DAN PEMBAHASAN}

Data hasil observasi motivasi siswa kelas X.3 pada materi pembelajaran avertebrata melalui model Group Investigation (GI) pada siklus I dapat dilihat dalam tabel 1. berikut:

\begin{tabular}{|c|c|c|c|c|}
\hline No & Aspek yang diamati & $\begin{array}{c}\text { Jumlah } \\
\text { siswa }\end{array}$ & $\begin{array}{c}\text { Persentase } \\
(\%)\end{array}$ & $\begin{array}{c}\text { Presentase } \\
\text { kelas }\end{array}$ \\
\hline 1 & Siswa tekun dalam menghadapi tugas & 26 & 81,25 & \multirow{8}{*}{$60,15 \%$} \\
\hline 2 & Ulet menghadapi kesulitan & 16 & 50 & \\
\hline 3 & Senang menyelesaikan tugas & 25 & 78,13 & \\
\hline 4 & Bekerja mandiri maupun kerjasama & 25 & 78,13 & \\
\hline 5 & Aktif bertanya atau berpendapat & 12 & 37,5 & \\
\hline 6 & Mempertahankan pendapatnya & 12 & 37,5 & \\
\hline 7 & Yakin pada pendirian & 12 & 37,5 & \\
\hline 8 & Mencari Informasi & 26 & 81,25 & \\
\hline
\end{tabular}

Tabel 1. Hasil observasi motivasi belajar

Tabel tersebut merupakan data yang diperoleh pada hasil observasi motivasi belajar siswa kelas X.3 pada siklus I, berdasrkan hasil tersebut akan berpengaruh pada prestasi belajar siswa yaitu sebagai berikut. 


\begin{tabular}{|c|c|c|c|c|}
\hline No & Perolehan nilai & Jumlah siswa & $\begin{array}{c}\text { Ketuntasan Klasi- } \\
\text { kal (\%) }\end{array}$ & Rata-Rata Nilai \\
\hline 1 & $<75$ & 21 & \multirow{2}{*}{$34,38 \%$} & 65,34 \\
\hline 2 & $\geq 75$ & 11 & 32 & \multirow{2}{*}{ Total jumlah siswa } \\
\hline
\end{tabular}

Tabel 2. Prestasi belajar siswa pada siklus I

\section{Data Hasil Observasi Motivasi Belajar Siswa}

Data hasil observasi motivasi belajar siswa kelas X.3 pada materi pembelajaran avertebrata melalui model Group Investigation (GI) pada siklus II dapat dilihat dalam tabel 3. berikut:

\begin{tabular}{|c|c|c|c|c|}
\hline No & Aspek yang diamati & $\begin{array}{c}\text { Jumlah } \\
\text { siswa }\end{array}$ & $\begin{array}{c}\text { Persentase } \\
(\%)\end{array}$ & $\begin{array}{c}\text { Persentase } \\
\text { kelas }\end{array}$ \\
\hline 1 & Siswa tekun dalam menghadapi tugas & 30 & 100 & \multirow{8}{*}{$77,82 \%$} \\
\hline 2 & Ulet menghadapi kesulitan & 19 & 61,29 & \\
\hline 3 & Senang menyelesaikan tugas & 30 & 96,77 & \\
\hline 4 & Bekerja mandiri maupun kerjasama & 29 & 93,55 & \\
\hline 5 & Aktif bertanya atau berpendapat & 21 & 67,74 & \\
\hline 6 & Mempertahankan pendapatnya & 16 & 51,61 & \\
\hline 7 & Yakin pada pendirian & 18 & 58,06 & \\
\hline 8 & Mencari Informasi & 29 & 93,55 & \\
\hline
\end{tabular}

Tabel 3. Hasil observasi motivasi belajar siswa siklus II

Berdasarkan tabel 3. Aktivitas motivasi belajar siswa selama proses belajar mengajar yang meliputi:

1. Ketekunan siswa dalam menghadapi tugas tergolong baik, siswa tekun mengerjakan tugas yang diberikan oleh guru. 31 siswa aktif dalam proses pembelajaran. hal ini mencirikan bahwa siswa termotivasi 100\% dari aspek ketekunan siswa.

2. Siswa ulet menghadapi tugas, benar benar rinci dalam menyikapi tugas yang diberikan guru terjadi kenaikan 3 siswa yang lebih ulet sehingga menjadi 19 siswa pada tahap siklus II ini.

3. Kesenangan menyelesaikan tugas, tidak semua siswa senang dalam menyelesaikan tugas tetapi ada pula yang senang. pada pengamatan ini 1 siswa tidak dengan senang dalam menyelesaikan tugasnya, hanya diam tanpa ekspresi yang dimunculkan. Tetapi dalam pengamatan pada siklus I ini termasuk baik karena lebih dari setengahnya siswa senang dalam menyelesaikan tugas.

4. Selama proses pembelajaran yang lebih menekankan pada stundent centered 
yakni bekerja mandiri atau bekerjasama dalam kelompoknya sudah terlihat dari beberapa kelompok yang melakukan diskusi dan saling bertukar pendapat serta mampu membagi - bagi tugas dalam kelompok.

5. Pada proses presentasi siswa mampu bertanya, walaupun berdasarkan pengamatan belum semua siswa dapat bertanya, dalam hal ini 21 siswa yang dapat bertanya pada kelompok yang presentasi didepan kelas maupun bertanya pada guru serta teman dalam sekelompoknya.

6. Mempertahankan pendapat terlihat ketika siswa menanggapi pertanyaan dari kelompok lain dan memberikan jawaban yang diminta. Berdasarkan pengamatan siklus II terjadi peningkatan bahwa ada 16 siswa yang saling tanggap menangapi.

7. Yakin pada pendirian, dalam penyampaian hasil diskusi maupun memberikan jawaban terlihat beberapa siswa yakin pada pendirianya, namun ada beberapa siswa pula yang masih binggung dengan pertanyaan maupun pernyataan yang diberikan oleh kelompok lain, dan diperoleh hasil persentase kelas yakni 58,06\% lebih baik dari siklus sebelumnya.

Dalam penerapan model Group Investigation (GI) bahwa siswa ditekankan untuk dapat mencari informasi yang diinginkan dalam proses pembelajaran. terlihat antusias siswa dalam mencari sumber maupun infora- masi baik dari referensi yang diperoleh maupun bertanya pada guru atau teman sekolompok dan terjadi peningkatan yakni 29 siswa mencari informasi.

Delapan aspek itulah yang dijadikan sebagai tolak ukur dalam keberhasilan motivasi belajar siswa pada siklus II dalam materi pembelajaran avertebrata yang meliputi filum Nemathelmintes, Annelida, dan Moluska melalui model Group Investigation (GI) telah mengalami peningkatan pada setiap aspek yang diamati dengan nilai persentase kelas sebesar 77,82\%. Hal ini berarti siswa pada siklus II dapat dikatakan aktif selama proses pembelajaran dan lebih termotivasi sehingga berdampak pada prestasi belajar siswa yang signifikan.

Peningkatan motivasi belajar biologi siswa pada siklus I dan siklus II dapat dilihat pada gambar berikut ini. 


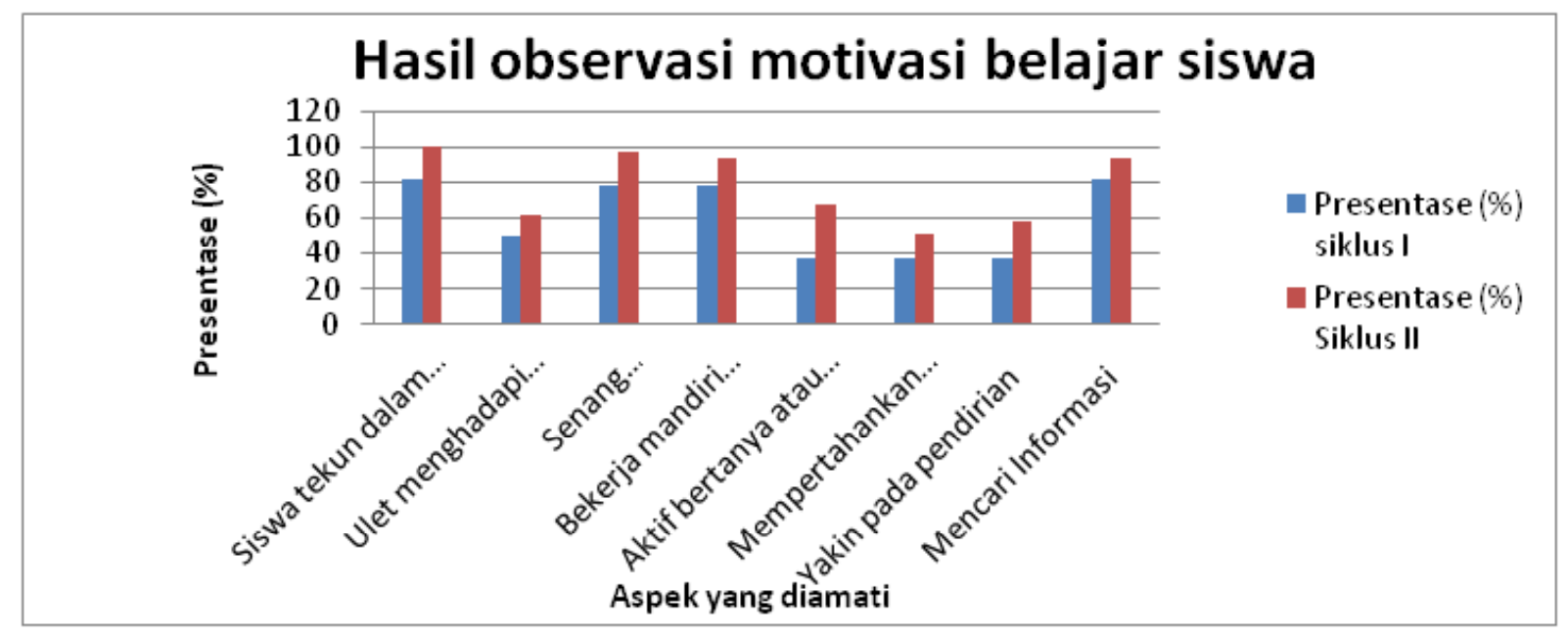

\section{Gambar 3. Diagram observasi motivasi belajar siswa siklus I dan siklus II}

Berdasarkan peningkatan motivasi belajar siswa pada siklus II yang mengalami peningkatan ini, maka hasil prestasi belajar juga mengalami peningkatan. Peningkatan prestasi belajar biologi siswa kelas X.3 pada

materi pembelajaran avertebrata melalui model Group Investigation (GI) pada siklus II dapat dilihat dalam tabel 4. berikut:

\begin{tabular}{|c|c|c|c|c|}
\hline No & Perolehan nilai & Jumlah siswa & $\begin{array}{c}\text { Ketuntasan Klasi- } \\
\text { kal (\%) }\end{array}$ & Rata-Rata Nilai \\
\hline 1 & $<75$ & 3 & \multirow{2}{*}{90,32} & 81,45 \\
\hline 2 & $\geq 75$ & 28 & & \\
\hline \multicolumn{2}{|c|}{ Total jumlah siswa } & 31 & & \\
\hline
\end{tabular}

Tabel 4. Prestasi belajar siswa siklus II

Berdasarkan tabel 4. prestasi belajar siswa pada siklus II pada materi pembelajaran avertebrata yang meliputi filum Nemathelmintes, Annelida dan Moluska melalui model Group Investigation dengan hasil motivasi belajar prosentase kelas sebesar 77,82 diperoleh prestasi hasil belajar ratarata siswa adalah 81,45 dengan persentase ketuntasan klasikal adalah 90,32\%. Hal ini menunjukkan bahwa siswa telah mampu be- radaptasi dengan model Group Investigation (GI) sehingga siswa dapat memahami dan menerima materi pembelajaran dengan baik, jika motivasi belajar siswa baik maka akan berdampak baik pula pada prestasi belajar siswa. 
Peningkatan prestasi belajar siswa siklus I dan siklus II dapat dilihat pada gambar berikut ini.

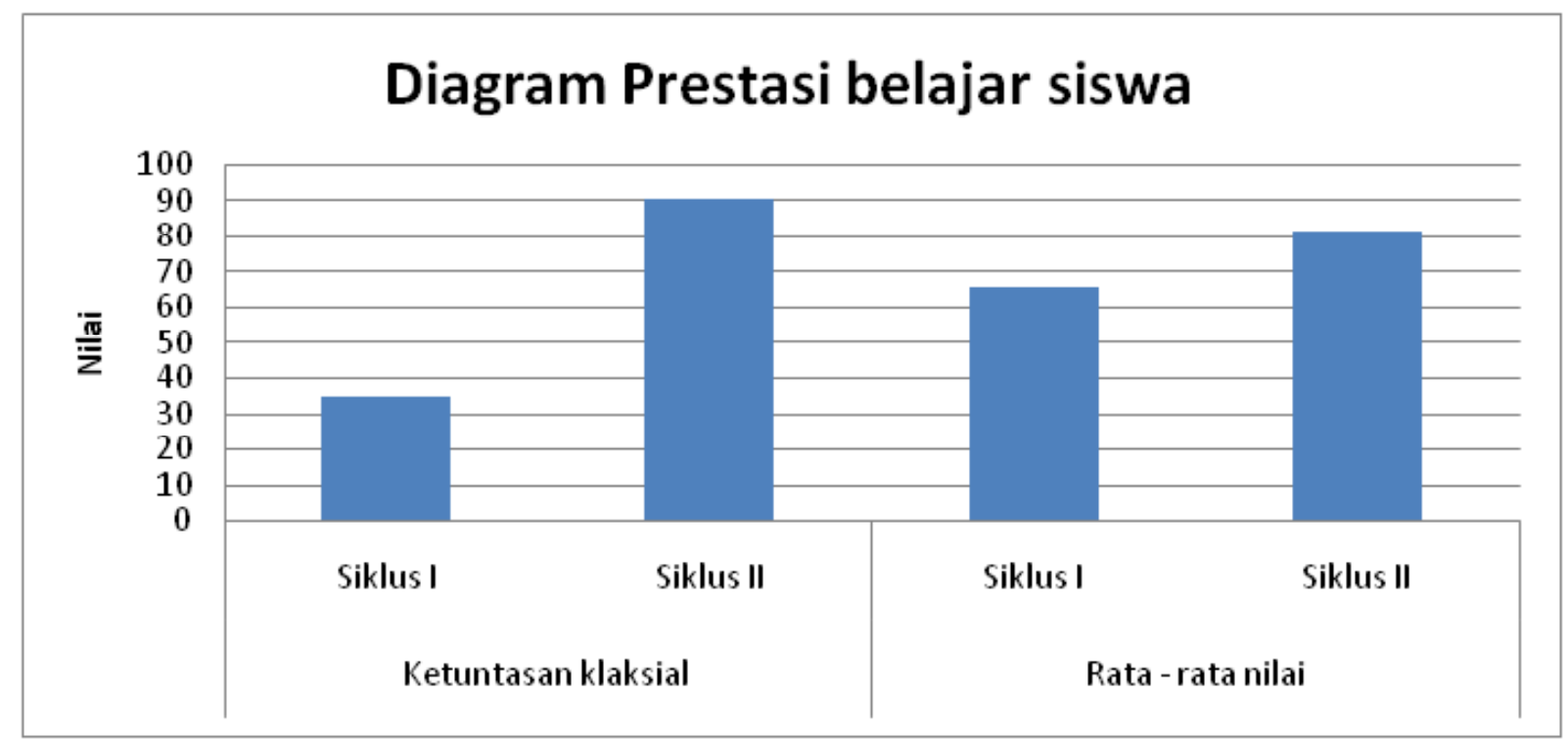

Gambar 4. Diagram prestasi belajar siswa siklus I dan siklus II.

Berdasarkan gambar 4 dapat diketahui bahwa motivasi belajar siswa mengalami peningkatan rerata nilai sebesar 16,11 dan peningkatan ketuntasan klasikal sebesar $55,94 \%$ Hal ini dikarenakan siswa telah mampu melaksanakan model Group Investigation (GI) sehingga penguasaan materi pembelajaran oleh siswa semakin baik yang pada akhirnya berimplikasi pada motivasi belajar siswa semakin baik dan berpengaruh pada meningkatnya hasil

belajar siswa dan peningkatan ketuntasan klasikal.

Berdasarkan data hasil penelitian yang diperoleh melalui observasi dan post tes pada materi pembelajaran avertebrata siswa kelas X.3 SMA Negeri I Pajangan dengan model Group Investigation (GI) diketahui bahwa terjadi peningkatan motivasi belajar siswa dalam setiap aspek penilaian pada setiap siklusnya.

Hasil observasi motivasi belajar biologi siswa terhadap pelaksanaan proses pembelajaran pada siklus I diketahui bahwa perhatian dan aktivitas siswa terhadap materi pembelajaran avertebrata yang disampaikan oleh guru sudah baik begitu pula aktivitas siswa walaupun untuk aktivitas bertanya dan merangkum materi pembelajaran masih cukup rendah. Oleh karena itu, perlu diadakan perbaikan salah satunya dalam meningkatkan partisipasi aktif siswa dalam mengajukan pertanyaan dalam proses pembelajaran dengan cara menggali siswa dengan permasalahan-permasalahan yang sering siswa jumpai dalam kehidupan sehari-hari sehingga dapat menumbuhkan keinginan siswa untuk lebih 
mengetahuinya.

Pelaksanaan pembelajaran biologi pada materi pembelajaran avertebrata dengan model Group Investigation (GI) pada kelas X.3 ditinjau dari segi keterlaksanaannya dapat terlaksana sesuai dengan sintaks-sintaks model Group Investigation (GI), hal ini dikarenakan oleh adanya sosialisasi sebelum diberlakukannya tindakan dan terjadinya kolaborasi yang baik antara guru, peneliti, dan observer.

Penerapan model Group Investigation (GI) untuk meningkatkan motivasi belajar siswa dilakukan dengan dua siklus, sesuai dengan hipotesis tindakan yang ditentukan, yaitu motivasi belajar siswa pada materi pembelajaran avertebrata mencapai kriteria ketuntasan minimum yang ditetapkan di SMA Negeri I Pajangan yakni 75.

Setelah pemberian tindakan selama dua siklus terjadi peningkatan motivasi belajar siswa, yaitu dari siklus I ke siklus II sehingga hasil refleksi pada siklus II diketahui bahwa indikator pencapaian telah terpenuhi dan siklus pembelajaran dihentikan. Adapun peningkatan motivasi belajar siswa pada tiap aspek kegiatan, yaitu:

\section{Keterlaksanaan proses pembelaja-} ran

Keterlaksanaan proses pembelajaran biologi dengan menggunakan model Group Investigation (GI) pada siklus I dan siklus II, dapat diketahui bahwa penerapan model Group Investigation (GI) di kelas X.3 SMA Negeri I Pajangan dapat dilaksanakan dengan baik sesuai dengan sintaks-sintaks model Group Investigation (GI). Proses pembelajaran di kelas pada siklus I, berdasarkan catatan guru bahwa siswa masih sedikit bingung belum teradaptasi dengan model tersebut sehingga pembelajaran kurang kondusif pada awal - awal pelaksanaan proses pembelajaran serta antusias aktifan siswa juga belum maksimal.

Namun berbeda hal pada proses pembelajaran pada siklus II siswa sudah dapat menyesuaikan dengan proses kegiatan belajar mengajar tersebut. Siswa terlihat antusias, mulai aktif bertanya serta dapat menyampaikan pendapatnya. Motivasi belajar siswa sudah muncul pada diri siswa masingmasing, yakni baik motivasi intrinsik maupun ekstrinsik. Motivasi intrinsik, timbulnya tidak memerlukan rangsangan dari luar karena memang telah ada dalam diri individu sendiri, yaitu sesuai atau sejalan dengan kebutuhannya. Sedangkan motivasi ekstrinsik timbul karena adanya rangsangan dari luar individu, misalnya dalam bidang pendidikan terdapat minat yang positif terhadap kegiatan pendidikan timbul karena melihat manfaatnya berdasrkan pada teori motivasi menurut Uno (2011: 4).

Berdasarkan hasil penelitian motivasi belajar siswa terdapat beberapa aspek penilaian yang dapat dicermati, yaitu: 
a. Ketekunan siswa dalam menyelesaikan tugas lebih dari $80 \%$ baik pada siklus I dan II. Peningkatan persentase ini menunjukkan bahwa siswa memiliki ketertarikan terhadap materi pembelajaran avertebrata melalui model Group Investigation (GI).

b. Ulet menghadapi tugas selama proses belajar mengajar berlangsung meningkat sebesar 11,29\% yaitu jumlah siswa yang ulet menghadapi tugas sebanyak 16 siswa pada siklus I dan pada siklus II sebanyak 19 siswa. Peningkatan persentase ini menunjukkan bahwa siswa tertarik dan berusaha mencari informasi untuk mencari pemecahan masalah.

c. Aktivitas siswa dalam menyelesaikan tugas dengan kelompoknya juga mengalami peningkata, pada siklus I terdapat 25 siswa dan pada siklus II ada 30 siswa. dalam menyelesaikan tugas siswa tetap cukup baik dan melebihi 50\%.

d. Bekerja mandiri maupun kerjasama mengalami kenaikan. Sebelumnya pada siklus I hanya $78,13 \%$ siswa sebanyak 25 orang meningkat pada siklus II sebesar 93,55\% dan sebanyak 29 siswa. Hal ini menandakan siswa sudah merespon permasalahan yang terjadi dan mampu bekerja dengan baik.

e. Bertanya yang disampaikan siswa lain, respon siswa baik dalam bertanya secara keseluruhan sudah sangat baik karena melebihi $90 \%$ siswa mendengarkan pe- nyajian hasil diskusi dari kelompok lain dan terjadi saling tanggap menanggapi.

f. Dalam mempertahankan pendapatnya beberapa siswa sudah mampu. Terlihat dari peningkatan antara siklus I 12 siswa sedangkan pada sklus II ada 16 siswa.

g. Yakin pada pendirian dapat dikatakan masih rendah pada siklus I yang hanya 12 siswa dan siklus II 18 siswa. Hal ini disebabkan rata-rata siswa kurang mapu memberanikan diri untuk mengeksplorasikan apa yang ada dalam benaknya. Sehingga perlu adanya dorongan motivasi dari luar, seperti pengaruh dari teman sekelompoknya untuk mendukung dalam menyampaikan pendapatnya.

h. Mencari informasi, dalam hal ini siswa dapat mengembangkan materi dengan cara mencari sumber belajar baik yang dibawa maupun dengan cara pergi ke perpustakaan. siswa juga memiliki buku acuan ajar yang ditetapkan sekolah, sehingga siswa cukup hanya dengan membaca buku acuan maka siswa sudah mendapatkan informasi yang baik. Beberapa siswa yang tampak aktif mencatat untuk melengkapi informasi yang tidak terdapat pada buku acuan ajar yang disampaikan oleh guru maupun bertanya denngan teman sendiri. Dari hasil observasi diperoleh 93,55\% siswa aktif mencari informasi. 
Peningkatan motivasi belajar siswa kelas X.3 SMA Negeri I Pajangan sudah sesuai dengan indikator yang telah ditetapkan, siswa telah mampu meningkatkan motivasi belajar, berpartisipasi secara aktif dalam proses pembelajaran yaitu tekun menghadapi tugas, ulet menghadapi tugas, bekerja mandiri maupun kelompok, aktif bertanya, mempertahankan pendapatnya, dan yakin pada pendirianya serta mencari informasi dalam melaksanakan tahapan Group Investigation (GI). Oleh karena itu, pelaksanaan tindakan dihentikan pada siklus II. Jadi, penerapan model Group Investigation (GI) pada materi pembelajaran avertebrata kelas X.3 SMA Negeri I Pajangan dapat dikatakan telah berhasil untuk meningkatkan motivasi belajar siswa.

Berdasarkan hasil peningkatan motivasi belajar tersebut maka berpengaruh terhadap hasil belajar atau prestasi siswa yang di tampakkan pada rata-rata nilai siswa pada siklus II yakni 81,45 yang sebelumnya 65,34 pada siklus I sehingga mengalami peningkatan sebesar 16,11 . Ketuntasan belajar siswa dengan standar ketuntasan minimal 75,00 mencapai $34,38 \%$ pada siklus I. Sedangkan pada siklus II 90,32\% ketuntasan belajar siswa mengalami kenaikan dari siklus I sebesar 55,94\%. Maka dapat disimpulkan jika motivasi belajar siswa tinggi maka prestasi belajar juga tinggi. Hal ini sesuai dengan yang diungkapkan Widyoko (2012:
233) yakni Motivasi belajar siswa memiliki pengaruh yang cukup kuat terhadap keberhasilan proses maupun hasil belajar siswa. Salah satu indikator kualitas pembelajaran adalah adanya semangat maupun motivasi belajar pada diri siswa. Ormrod (2003) menguraikan bagaimana pengaruh motivasi terhadap kegiatan belajar sebagai berikut.

Motivation hasseveral effect on studentslearningand behavior: It directs behavior toward particular goal. It leads to increased effort and energy. It increases initiation of, and persistence in activities. It enhances cognotive processing. It lead to improved performance (Omrod, 2003: 368 $-369)$.

Motivasi memiliki pengaruh terhadap perilaku belajar siswa, yaitu motivasi mendorong meningkatnya semangat dan ketekunan dalam belajar. Motivasi belajar memegang peranan yang penting dalam memberi gairah, semangat dan rasa senang dalam belajar sehingga siswa yang mempunyai motivasi tinggi mempunyai energi yang banyak untuk melaksanakan kegiatan belajar yang pada akhirnya akan mampu memperoleh prestasi yang lebih baik. Hal ini berarti bahwa proses pembelajaran biologi pada materi pembelajaran avertebrata dengan menggunakan model Group Investigation (GI) dapat terlaksana dengan baik.

Menurut Sharan (Tianto, 2011: 80) membagi langkah - langkah pelaksa- 
naan model Group Investigation(GI) meliputi 6 fase yaitu memilih topik, perencanaan kooperatif, Implementasi, analisis dan sintesis, presentasi hasil final serta evaluasi. Dari langkah - langkah tersebut dapat mengajarkan siswa ketrampilan komunikasi dan proses kelompok yang baik. Sehingga dapat benar - banar mengaktifkan siswa selama proses pembelajaran di kelas terutama kelas X.3.

Proses pembelajaran pada materi pembelajaran avertebrata baik pada siklus I maupun siklus II, peran guru hanya sebagai fasilitator yaitu memberikan pengarahan seperlunya pada siswa. Keaktifan siswa lebih ditekankan pada pembelajaran ini. Dengan adanya keaktifan tersebut akan menumbuhkan motivasi belajar yang tinggi pada siswa dan pada akhirnya akan berpengaruh pula terhadap prestasi belajar siswa. Hal ini sesuai dengan teori Mc Donald (Oemar, 2009: 173) "Motivation is a energy change within the person characterized by affective arausal and anticipatory goal reactions." Motivasi adalah sebuah perubahan energi di dalam pribadi seseorang yang ditandai dengan timbulnya afektif dan reaksi untuk mencapai tujuan. Dalam penelitian ini yakni motivasi belajar siswa.

Berdasarkan hasil Peningkatan motivasi belajar siswa dan prestasi belajar siswa kelas X.3 SMA Negeri I Pajangan maka dapat dikatakan bahwa usaha perbai- kan pembelajaran biologi dengan penerapan model Group Investigation (GI) sebagai salah satu usaha perbaikan hasil belajar biologi berhasil dengan baik. 


\section{KESIMPULAN DAN SARAN}

\section{KESIMPULAN}

Berdasarkan hasil penelitian, maka kesimpulan dari penelitian ini adalah:

1. Peningkatan motivasi belajar biologi siswa kelas X.3 SMA Negeri I Pajangan tahun ajaran 2011/2012 pada pembelajaran biologi materi pembelajaran avertebrata dapat tercapai melalui dua siklus tindakan.

2. Pembelajaran dengan menggunakan model Group Investigation (GI) pada materi pembelajaran avertebrata siswa kelas X.3 SMA Negeri I Pajangan tahun ajaran 2011/2012 mengalami peningkatan yaitu:

a. Motivasi belajar biologi siswa dalam mengikuti kegiatan pembelajaran meningkat pada siklus I 60,15\% siswa aktif dan $77,82 \%$ pada siklus II.

b. Peningkatan prestasi belajar biologi siswa yang berupa pengaruh dari hasil motivasi belajar siswa ditunjukkan dengan nilai rata-rata kelas post tes siswa pada siklus I sebesar 65,34 dan 81,45 pada siklus II.

\section{SARAN}

Berdasarkan hasil pengamatan dan penelitian yang telah dilaksanakan, maka dapat diajukan saran-saran sebagai berikut:
1. Model pembelajaran model Group Investigation (GI) hendaknya dapat diterapkan oleh guru pada materi pembelajaran avertebrata pada semester berikutnya dan pada materi pembelajaran lainnya.

2. Kepada peneliti lain yang akan melakukan penelitian serupa, tahap persiapan sangat diperlukan, terutama mengenai instrument penelitian harus disiapkan secara matang terlebih dahulu sebelum terjun melaksanakan penelitian di kelas.

3. Penerapan model model Group Investigation (GI) dalam penelitian tindakan kelas harus dilakukan sesuai dengan sintak-sintak model pembelajaran tersebut, seorang peneliti harus peka terhadap situasi dan kondisi kelas terutama terhadap siswa, agar masalah yang teridentifikasi di kelas tersebut dapat terpecahkan dengan solusi yang sesuai.

\section{UCAPAN TERIMA KASIH}

Ucapan terima kasih penulis kepada Rektor universitas Ahmad Dahlan, Dekan fakultas keguruan dan ilmu pendidika, ketua program studi pendidikan biologi serta kepala sekola SMA Negeri I Pajangan Yogyakarta atas bantuan dan dukungan yang diberikan sehingga penelitian ini dapat terlaksana dengan baik. 


\section{DAFTAR PUSTAKA}

Arikunto, Suharsimi. 2009. Dasar- Dasar Evaluasi Pendidikan. Jakarta: Bumi Akara. . 2010. Penelitian Tindakan Untuk Guru, Kepala Sekolah dan Pengawas. Jakarta: Bumi Akara. 2011. Penelitian Tindakan Kelas. Jakarta: Bumi Aksara.

Baumfield, Vivienne. Elaine Hall. Kate Wall. 2011. Action Research in the Classroom. Yogyakarta: Pustaka Pelajar.

Djamarah, Syaiful Bahri. 2010. Guru \& Anak Didik dalam Interaksi Edukatif. Jakarta: Rineka Cipta.

Mardapi, Djemari. 2008. Teknik Penyusunan Instrument Tes dan Non Tes. Yogyakarta: Mitra Cendekia.

Pratiwi, Sri Maryati, Srikini, Suharno, Bambang. 2007. Biologi I untuk SMA. Jakarta: Erlangga.

Prawirohartono, Slamet. Sri hidayati. 2007. Sains Biologi ISMA/MA. Jakarta: Bumi Akasara.
Purwanto, Ngalim. 2006. Prinsip - prinsip dan Teknik Evaluasi Pengajaran. Bandung: PT. Remaja Rosdakarya.

Sardiman. 2010. Interaksi dan Motivasi Belajar Mengajar. Jakarta: PT Raja Grafindo Persada.

Sugiyono. 2011. Metode Penelitian Pendidikan Pendekatan Kuantitatif, Kualitatif, dan R\&D. Bandung: Alfabeta.

Susilo, Muhammad Joko. 2009. Sukses dengan Gaya Belajar. Yogyakarta: Pinus.

Uno, Hamzah. 2011. Teori Motivasi dan Pengukuranya. Jakarta: bumi Aksara.

Widyoko, Eko Putro. 2012. Teknik Penyusunan Instrumen Penelitian. Yogyakarta: Pustaka Pelajar. 